\title{
THE IMPACT OF INTERVENTION MEASURES ON SEXUAL HARASSMENT IN THE FILM AND TELEVISION INDUSTRY
}

Ben Eng, Marshall University, Huntington, WV, U.S.A.

Ralph E. McKinney, Jr., Marshall University, Huntington, WV, U.S.A.

Lawrence P. Shao, Slippery Rock University, Slippery Rock, PA, U.S.A.

dx.doi.org/10.18374/JIMS-19-1.1

\begin{abstract}
Since 2017, increased sexual harassment incidents have been reported in Hollywood; yet, little guidance has been offered on how organizations, which are informally governed by their network members, can effectively reduce sexual harassment. Building upon the theory of network governance, this paper suggests social mechanisms, which are used to coordinate and safeguard exchanges between Hollywood organizations, are more effective at reducing incidents of workplace sexual harassment than traditional strategies. These social mechanisms direct change to the macroculture through collective sanctions that damage the perpetrators reputation and restrict access to network opportunities. In essence, perpetrators become toxic assets that Hollywood avoids and this avoidance is similar to economic sanctions that can deter sexual harassment.
\end{abstract}

Keywords: Sexual Harassment, Network Governance, Intervention, Film, Sanctions 